\title{
Uptake and Accumulation of Cadmium by Ophryotrocha diadema (Polychaeta)
}

\author{
K. Klöckner \\ Biologische Anstalt Helgoland, Palmaille 9, D-2000 Hamburg 50, Federal Republic of Germany
}

\begin{abstract}
Cadmium uptake by the deposit-feeding polychaete Ophryotrocha diadema is a non-linear process related to exposure time and metal concentration in the ambient seawater $\left(20^{\circ} \mathrm{C} ; 31 \% \mathrm{wS}\right)$. Maximum body loads of $1700 \mathrm{ppm} \mathrm{Cd} \mathrm{were} \mathrm{found}$ in adult worms (up to $0.1 \mathrm{mg}$ dry weight) after 64 -day exposure to $1000 \mathrm{ppb} \mathrm{Cd}$. Distinct saturation of absorption was not reached during this time. Accumulation factors decreased exponentially with increasing contamination levels. Accumulation factors were 7900 to 1700 , calculated on a dry weight basis, corresponding to 3400 to 660 estimated on a theoretical volume basis of single worms in levels of 10 to $1000 \mathrm{ppb} \mathrm{Cd}$. Cd content of 62 - to 116 -day-old worms of three consecutive generations subjected to permanent contamination did not increase from the $\mathrm{P}$ - to the $\mathrm{F}_{2}$-generation. A linear correlation exists between Cd absorption of newly deposited egg masses and experimental Cd concentrations. Cd loads of egg masses were extremely low ( 12 to $280 \mathrm{ppm} \mathrm{Cd}$ dry weight in 50 to $1000 \mathrm{ppb} \mathrm{Cd}$ contamination) compared with parental organisms. Cd content of the egg masses also did not increase within consecutive generations. It is, therefore, assumed that parentally accumulated Cd loads are not transferred to the offspring. Contamination of egg masses probably occurred after spawning, due to sorption of the metal by the mucoid layer encapsulating the eggs, since similar results were noted for Cd sorption by food particles (fragmented spinach).
\end{abstract}

\section{INTRODUCTION}

The pollution of oceans and coastal waters due to heavy metals is presently receiving detailed attention in Volume $\mathrm{V}$ of 'Marine Ecology' (Kinne, in press). For many marine invertebrates, including several polychaete species, both in-situ body loads and experimental uptake of heavy metals have been determined. In general, regulatory capacities for absorption of 'nonessential' metals such as $\mathrm{Hg}$, $\mathrm{Pb}$ or $\mathrm{Cd}$ are poor (Bryan, 1976). Much information is available on bioaccumulation of individuals during ontogenetic life stages, whereas only few data exist on the transfer of parental body burdens to consecutive generations via the egg (Oshida, 1976, 1977; Rehwoldt and Karimian-Teherani, 1976).

The present paper attempts to shed some light on the kinetics of cadmium uptake by the deposit-feeding hermaphroditic polychaete Ophryotrocha diadema during reproductive cycles of three generations. Some effects of $\mathrm{Cd}$ on reproduction of $O$. diadema have been reported recently by Reish and Carr (1978). This paper will be discussed together with data on acute and chronic effects of the metal in relation to uptake in a forthcoming article (Klöckner, in preparation).

Ophryotrocha diadema was selected as a suitable bioassay organism for the following reasons: (1) as a typical deposit-feeder, bioaccumulative capacities of toxicants might be demonstrated within a bottom-food chain; (2) its relatively short reproductive cycle (3 weeks) allows experiments over several generations to be made within a reasonable time; (3) its high reproductive potential facilitates investigations with sufficient numbers of experimentals for statistical analysis; (4) standard methods for cultivation are available (Åkesson, 1975, 1976).

Cadmium was chosen as test pollutant because of its well-documented toxic characters, including accumulative properties in biota. Furthermore, there exists a well developed set of microanalytical methods for biological monitoring of this metal. The analytical procedures used in this study have been described by Sperling (1976, 1977a, 1977b, 1978).

\section{MATERIALS AND METHODS}

\section{Stock Cultures}

Isogenetic strains of Ophryotrocha diadema (originally collected from subtidal areas in Los Angeles Harbour, California, USA) were supplied by Dr. B. 
Akesson (University of Göteborg, Sweden). The laboratory cultures used in this study have been maintained over numerous consecutive generations, since July 1976. Stock populations were kept in hemispherical glass bowls with $70 \mathrm{ml}$ unaerated, filtered (Seitz K 5) and sterilized North Sea water $\left(20^{\circ} \mathrm{C}, 32\right.$ to $\left.34 \% \mathrm{~S}\right)$ under standard mass culture conditions. The worms were fed on fragmented spinach in excess ( $\AA$ kesson, 1970); water and food were changed once a week.

\section{Cadmium Exposure Experiments}

Cadmium absorption rates were investigated in two groups of worms of different pre-exposure conditions: (1) adults raised in uncontaminated media; (2) larvae and offspring of uncontaminated worms, which were permanently exposed to different $\mathrm{Cd}$ levels through 3 generations. Simple statistic test methods of correlation between $\mathrm{Cd}$ uptake and exposure time were applied to both groups (Wang programme No. 6462).

Cadmium exposure of the first group started when the test individuals had reached maturity at a developmental stage of about 15 segments $(0.1 \mathrm{mg}$ dry weight). $\mathrm{Cd}$ concentrations employed were 10,100 and 1000 $\mathrm{ppb}$ with exposure times ranging from $1 \mathrm{~h}$ to 64 days. The second set of experiments started at the 4 -segment larval stage. These individuals were exposed to 20,50 , $100,250,500$ and $1000 \mathrm{ppb} \mathrm{Cd}$ until reproduction occurred. Exposure to $\mathrm{Cd}$ was continued during three consecutive generations. Accumulation of the metal was determined in samples of 62- to 116-day-old adults and in their egg masses, which were collected from contaminated media within 2 days after deposition.

Hemispherical glass bowls containing 20 individuals in $50 \mathrm{ml}$ of test solution $\left(20^{\circ} \mathrm{C} ; \quad 31 \% \mathrm{~S}\right)$ were employed for both groups. Test media and precontaminated food in excess were changed once a week, when data on survival, growth and egg production were also noted (Klöckner, in preparation).

Cadmium stock solutions containing $1 \mathrm{~g} \mathrm{Cd}^{++} \mathrm{l}^{-4}$ (bidistilled water, $\mathrm{Cd}$ as dissolved $\mathrm{CdCl}_{2}$ ), were first diluted with double-distilled water, and then added in appropriate amounts to filtered and sterilized seawater (32 to $34 \%$ s), thereby reducing salinity to approximately $31 \%$ S. These test solutions were kept for several weeks in 5-1 glass bottles in darkness at room temperature $\left(20\right.$ to $\left.22^{\circ}, \mathrm{z}\right)$. Initially, Cd concentrations in these bottles decreased up to $10 \%$ after 4 wreeks storage. In order to compensate possible $\mathrm{Cd}$ binding to the glass walls, bottles and experimental bowls were precontaminated for $24 \mathrm{~h}$ with test solution before they were charged

All life-cycle stages of Ophryotrocha diadema were fed on commercial, deep-frozen spinach, suspended in sterilized seawater. The spinach was fragmented in a food mixer and washed twice in sterilized seawater. In order to quantify food supply, amounts of $100 \mathrm{ml}$ 'mash' of a 0.6 to $1.5 \mathrm{~mm}$ 'fraction' (PVC-sieves) were deepfrozen again and resuspended in $1 \mathrm{l}$ seawater or in $\mathrm{Cd}$ test solutions of appropriate concentration. After 2 days of precontamination, the food suspensions were given to the worms in portions of 0.2 to $5 \mathrm{ml}$, according to their size. Mean spinach dry weight in the food suspensions was determined as $4.4 \mathrm{~g} \mathrm{l}^{-1}$.

\section{Chemical Analysis}

Analysis in water samples, food, worms and egg masses was carried out by Dr. K.-R. Sperling (Biologische Anstalt Helgoland) by means of flameless atomic absorption spectrophotometry, using a Perkin Elmer AAS 400 with graphite furnace HGA 74 and automatic sampler AS-1. Determinations were performed on samples and subsamples of $1 \mathrm{ml}$ seawater, $0.1 \mathrm{~g}$ spinach (dry weight), batches of 10 worms 10.3 to $1 \mathrm{mg}$ dry weight) or 6 to $16 \mathrm{egg}$ masses $(0.2 \mathrm{mg}$ mean dry weight). Biological samples were cleaned from adherent food particles and faeces, washed 3 times in uncontaminated seawater, and passed within $5 \mathrm{~min}$, by means of a micropipette $(10 \mu \mathrm{l}$ volume), through baths of 5,50 and $100 \%$ methanol, of $5 \mathrm{ml}$ volume each. For drying $\left(6 \mathrm{~h}\right.$ at $55^{\circ} \mathrm{C}$ ) and weighing (Cahn Electrobalance), material was placed on 'parafilm' sheets weighing about $12 \mathrm{mg}$. Dried samples were digested for $24 \mathrm{~h}$ with nitric acid, diluted with double-distilled water and injected for analysis into the graphite furnace of the AAS. 2 to 4 subsamples were taken for analysis. Mean $\mathrm{Cd}$ contents were calculated as ppb Cd in water of ppm $\mathrm{Cd}$ dry weight in biological materials (simplified values, meaning $\mu \mathrm{g} \mathrm{Cd} \mathrm{l^{-1 }}$ seawater or ng $\mathrm{Cd} \mathrm{mg}^{-1}$ dry weight).

The experimental levels of cadmium in the test solutions were up to $10 \%$ lower than intended. Mean $\mathrm{Cd}$ contents of controls were $0.9 \mathrm{ppb}$ for seawater, $0.8 \mathrm{ppm}$ for dried spinach, and $5.3 \mathrm{ppm}$ for dried worms. Only the latter value reached accumulation levels in individuals obtained in the lowest experimental contamination (10ppb Cd) after up to $6 \mathrm{~h}$ exposure.

\section{RESULTS}

\section{Kinetics of Uptake by Adult Ophryotrocha diadema}

Cadmium uptake by the test worms expressed as total body load, was dependent on exposure time and contamination level. In the lowest $\mathrm{Cd}$ concentration (10ppb), uptake reached significantly higher levels 


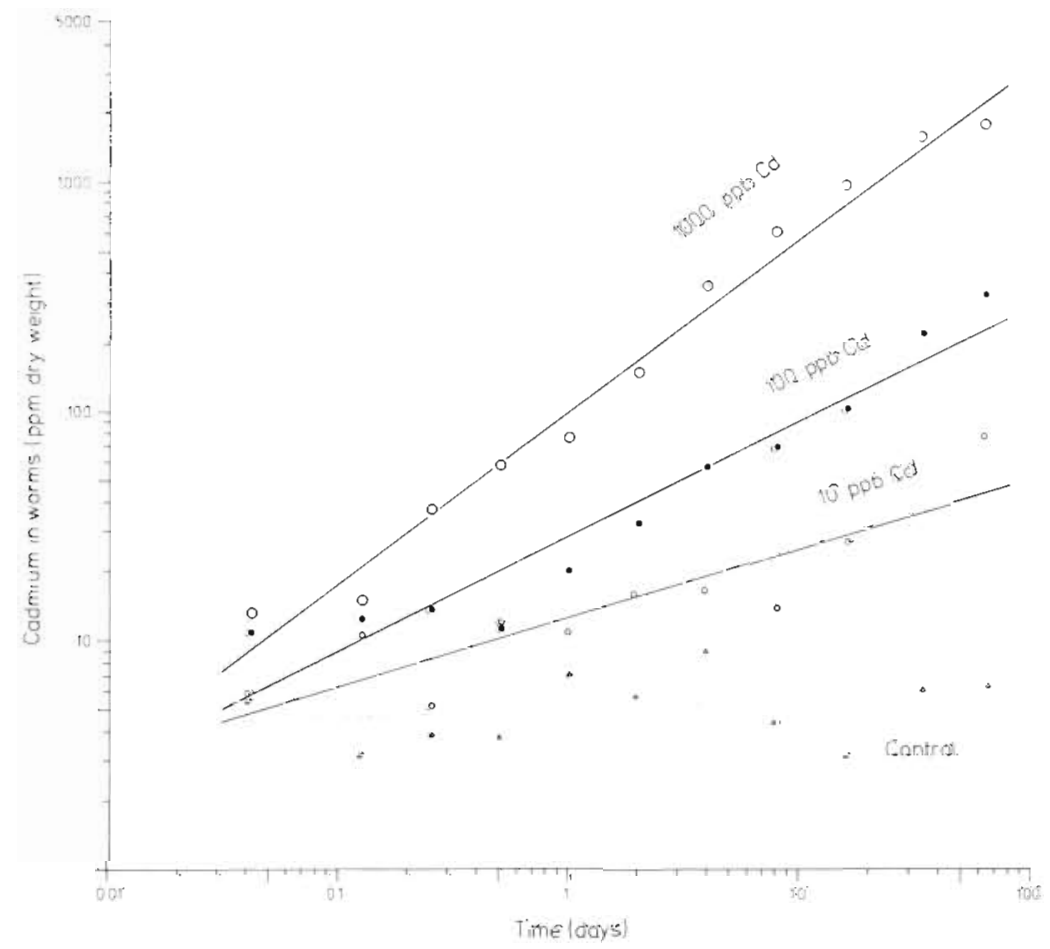

Fig. 1. Ophryotrocha diadema. Cadmium uptake by adults from contaminated seawater (10 to $1000 \mathrm{ppb} \mathrm{Cd}$ ). Regression lines of Cd uptake follow text Eq. (1) to (4). Each point represents pooled metal burdens of 10 worms (corresponding to $0.76 \mathrm{mg}$ mean dry weight). $20^{\circ} \mathrm{C} ; 31 \% \mathrm{~S}$

after $12 \mathrm{~h}$ exposure, in medium and high concentrations (100 ppb and $1000 \mathrm{ppb}$ ) already after 1 h exposure; mean control values were $5.3 \mathrm{ppm} \mathrm{Cd}$, dry weight. After 64 days, $C d$ content in exposed individuals reached 79, 315 and $1708 \mathrm{ppm} \mathrm{Cd}$ (dry weight), and exceeded control values by factors of ca. 15, 60 and 320 , in 10,100 and $1000 \mathrm{ppb} \mathrm{Cd}$, respectively. A nonlinear relationship between absorption rates and exposure time has been found, as indicated in Figure 1. Plotted in double-logarithmic scale, the data resulted in straight lines following equations of $y=a x^{b}$ :

$$
\begin{aligned}
& y=4.93 x^{0.03} ; r=0.22 \text { (control) } \\
& y=12.52 x^{0.30} ; r=0.88(10 \mathrm{ppb} \mathrm{Cd}) \\
& y=28.15 x^{0.49} ; r=0.96(100 \mathrm{ppb} \mathrm{Cd}) \\
& y=99.47 x^{0.74} ; r=0.99(1000 \mathrm{ppb} \mathrm{Cd})
\end{aligned}
$$

where $y=\mathrm{Cd}$ content of worms, and $x=$ exposure time. Allometric parameters $a$ and $b$ increased with contamination level.

In controls, cadmium content averaged $5.3 \pm$ $1.8 \mathrm{ppm}$ Cd (dry weight). The low slope of Equation (1) indicates that no significant accumulation occurred in the controls within the experimental period.

Maximum absorption of the metal occurred within a period of about 2 weeks. No distinct saturation level of uptake seemed to be reached within 64 days, although the time curve approached asymptotic values at the highest cadmium contamination.
Accumulation factors of cadmium loads after 64 days decreased exponentially with increasing contamination levels. Calculated on a dry weight basis, a low contamination of $10 \mathrm{ppb}$ yielded a factor of 7900, which was reduced to 3150 and 1700 in medium-and highcontamination levels of 100 and $1000 \mathrm{ppb} \mathrm{Cd}$, respectively. Corresponding to a theoretical water volume of about $0.25 \mu$ per test individual, accumulation factors would be about 0.4 fold lower, ranging from 3400 to 660 for 10 to $1000 \mathrm{ppb} \mathrm{Cd}$ contamination levels.

\section{Accumulation in Consecutive Generations}

Three consecutive generations of Ophryotrocha diadema, starting with uncontaminated larvae of a Pgeneration, were raised in cadmium-contaminated test media (concentrations: 20 to $1000 \mathrm{ppb} \mathrm{Cd}$ ). The effects of the toxicant on survival, growth and reproduction will be reported in a forthcoming paper (Klöckner, in preparation).

Accumulation of cadmium by adult worms from the $\mathrm{P}$ - to the $\mathrm{F}_{2}$-generation and the metal contents of the egg masses of the same individuals are plotted in Figures 2 and 3 .

Within generations, no significant increase of accumulation was found after a total exposure time of 274 days. Pooling of the data of all generations $\left(P\right.$ to $\left.F_{2}\right)$ 


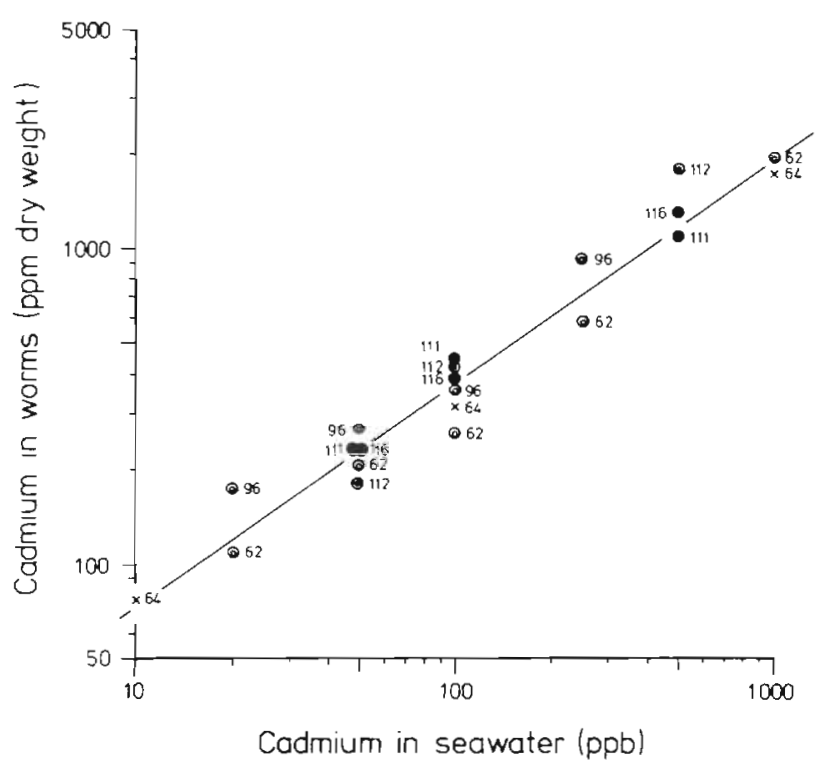

Fig. 2. Ophryotrocha diadema. Accumulation of cadmium by 3 consecutive generations from contaminated seawater. Regression line of $\mathrm{Cd}$ burdens follows text Eq. (5). Open circles: P-generation; partly filled circles: $F_{1}$-generation; filled circles: $F_{2}$-generation crosses: compiled data from Fig. 1, for comparison. Numbers next to data points indicate individual exposure in days ( $=$ age of worms from hatching). Each point represents pooled metal burdens of 10 worms (corresponding to $0.62 \mathrm{mg}$ mean dry weight). $20^{\circ} \mathrm{C}$; $31 \% \mathrm{~S}$

with individual contamination from 62 to 116 days, showed accumulation to be correlated non-linearly with the degree of contamination in the range 50 to $1000 \mathrm{ppb} \mathrm{Cd}$, and could be described as an exponential function of $y=a x^{b}$, resulting in a straight line on a double-logarithmic scale:

$$
y=13.98 x^{0.71} ; r=0.98 \quad(5)
$$

where $y=\mathrm{Cd}$ contents in worms, and $x=\mathrm{Cd}$ contamination of seawater.

Accumulation by adult worms after 64 days exposure (Fig. 1) were well in accordance with this equation. Cadmium loads of the egg masses (Fig. 3) obtained from part of the test individuals shown in Figure 2 were about one order of magnitude lower than those determined for parental individuals. Cd concentrations amounted to about 12 to $280 \mathrm{ppm}$ for eggs, the parents of which had been exposed to 50 to $1000 \mathrm{ppd} \mathrm{Cd}$, respectively. The correlation between $\mathrm{Cd}$ sorption of the egg masses and the degree of precontamination of parental generations was almost linear, following the equation:

$$
y=0.23 x^{1.01} ; r=0.98 \quad(6)
$$

where $y=C d$ content in egg masses, and $x=C d$ contamination of seawater.

No significant difference could be found between cadmium sorption in egg masses of the P-generation (62 days individual exposure) and of the $\mathrm{F}_{2}$-generation

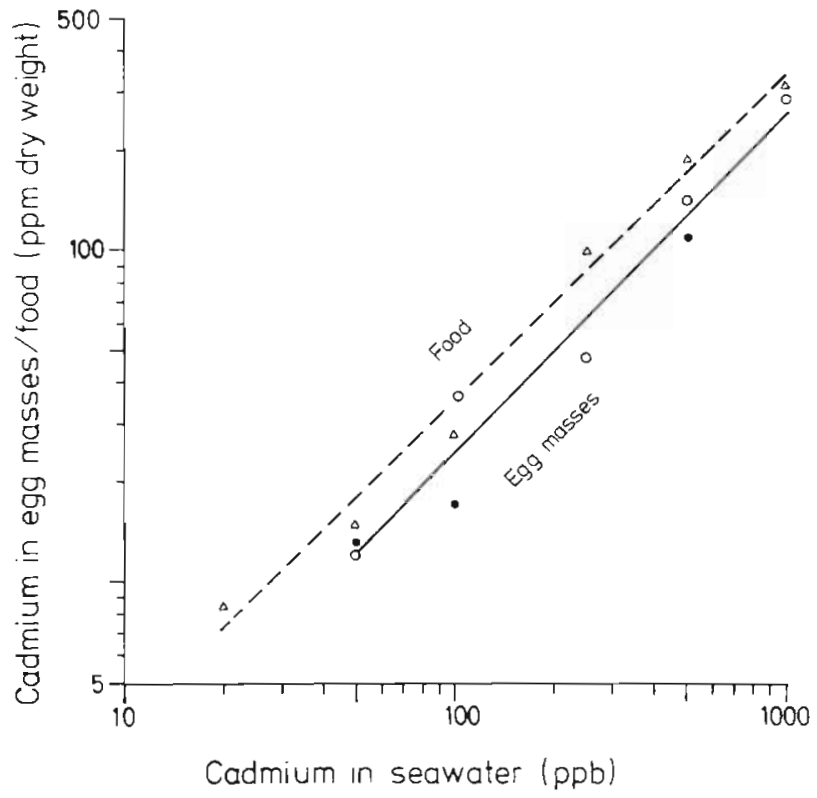

Fig. 3. Ophryotrocha diadema. Cadmium content of egg $\mathrm{m}$ a s s e s from parental organisms exposed to 20 to $1000 \mathrm{ppb}$ $\mathrm{Cd}$ over 3 generations (eggs were collected from contaminated media within 2 days after deposition), and f o o d (fragmented spinach exposed to 10 to $1000 \mathrm{ppb} \mathrm{Cd}$ for 4 days). Regression lines for Cd sorption follow text Eq. (6). (= egg masses) and text Eq. (7) (= spinach). Open circles: eggs from P-generation (parental contamination 62 days); filled circles: eggs grom $\mathrm{F}_{2}$-generation (parental contamination 116 days); triangles: spinach. Each point represents pooled metal content of 6 to 16 egg masses (corresponding to $0.21 \mathrm{mg}$ mean dry weightj or sample of $112 \mathrm{mg}$ mean dry weight of spinach. $20^{\circ} \mathrm{C} ; 31 \%$ s

(116 days individual exposure; 215 days exposure from P-generations when the experiment had started).

Cadmium content of the food (fragmented spinach) after 4 days exposure yielded a similar and also almost linear correlation with the contamination levels in the egg masses which had been contaminated by the test media for up 2 days (Fig. 3):

$$
y=0.38 x^{0.98}, r=0.99
$$

where $y=C d$ content in spinach, and $x=C d$ contamination of seawater.

\section{DISCUSSION}

The present study demonstrates: cadmium uptake by Ophyrotrocha diadema increases exponentially with time (Fig. 1); the relative accumulation of the metal decreases with increasing experimental concentrations (Fig. 2). At contamination levels of 10 to $1000 \mathrm{ppb}$ $\mathrm{Cd}$, accumulation factors were 7900 to 1700 , respectively, when calculated on a dry weight basis; or 3400 to 660 , when estimated on a theoretical volume basis for single worms. Regulation capacity, however, must be considered poor, since no distinct equilibrium of uptake and loss seemed to be reached after 64 days, 
although the time curve approached asymptotic values at the highest contamination level of $1000 \mathrm{ppb} \mathrm{Cd}$. The results will be further discussed in context with additional experiments, where the acute $\mathrm{Cd}$ toxicity in adult individuals was determined, revealing a $96-\mathrm{h}$ $\mathrm{LC}_{50^{-}}$value (concentration causing $95 \%$ mortality) of about 1600 ppb Cd (Klöckner, in preparation).

Accumulation by Ophryotrocha diadema resulted in a maximum body load of $1700 \mathrm{ppm}$ Cd (dry weight) after 64 days in $1000 \mathrm{ppb} \mathrm{Cd}$. This value is extremely high compared with findings in other polychaetes. $\mathrm{Cd}$ uptake after 32 days exceeded that of Nereis diversicolor (Bryan and Hummerstone, 1973) by 7.7 times. Since the mean dry weight of the adult $O$. diadema used in the present study was $0.1 \mathrm{mg}$ or less, while $N$. diversicolor weighed $50 \mathrm{mg}$, uptake rates may depend on body size.

Reports on the accumulation of cadmium by marine invertebrates collected from different sites of estuarine and coastal regions have shown body loads to be correlated to ambient contaminations of water and sediment, but to differ within taxonomic groups as well as with size or age of individuals (Boyden, 1977). Extreme values of up to $130 \mathrm{ppm} \mathrm{Cd}$ (dry weight) were found in molluscs, especially in Crassostrea gigas from Tasmanian waters (Ayling, 1974) and Mytilus edulis from the Bristol Channel, U. K. (Nickless et al., 1972), where background contamination in sediments amounted to up to $6 \mathrm{ppm} \mathrm{Cd} \mathrm{(dry} \mathrm{weight).} \mathrm{Comparatively} \mathrm{low}$ accumulation, on the other hand, was found in the sediment-living polychaete Nereis diversicolor from south-west England by Bryan and Hummerstone (1973), who recorded up to 9 ppm Cd (dry weight) in sediments and only $3.6 \mathrm{ppm} \mathrm{Cd}$ (dry weight) in the worms. Highest values of laboratory accumulation from sublethal Cd concentrations have been observed in $N$. diversicolor by the same authors (1973) and in the freshwater crayfish Orconectes propinquus propinquus by Gillespie et al. (1977). These test species contained up to 200 or $530 \mathrm{ppm} \mathrm{Cd}$ (both dry weight) after contamination of $1000 \mathrm{ppb}$ over periods of 32 ( $N$. diversicolor) or 8 days (O. propinquus propinquus).

Recent investigations on the absorption of cadmium and other 'non-essential' heavy metals by marine invertebrates have included mainly species of molluscs, crustaceans and some polychaetes. Uptake turned out to depend on the ambient concentration in the water, food or sediment and to be often correlated with factors such as temperature, salinity, chelating agents or other interacting metals. Capacities to regulate $\mathrm{Cd}$ accumulation have appeared to be generally poor, bur they differ widely within taxonomic groups.

Linear uptake of cadmium over several weeks and accumulation factors which were directly proportional within wide ranges of ambient concentrations have been observed in Mytilus edulis (Jackim et al., 1977 ; George and Coombs, 1977). This species did not regulate $\mathrm{Pb}$ uptake either (Schulz-Baldes, 1974). Continuous accumulation of $\mathrm{Cd}$ by Crassostrea virginica from solutions containing $5 \mathrm{ppb}$ during a 9-month period was reported by Zaroogian and Cheer (1976). Nereis diversicolor also seems unable to regulate $\mathrm{Cd}$ absorption over periods of 32 days in experimental concentrations up to $1000 \mathrm{ppb} \mathrm{Cd}$ (Bryan and Hummerstone, 1973). Several crustaceans have also exhibited poor regulatory capacities. After a rapid short-time, (hours) accumulation, long-term linear absorption increase without reaching a steady state was noted after 8 days in Orconectes propinquus propinquus (Gillespie et al., 1977) and after 30 days in Crangon crangon (Dethlefsen, 1977). Exponential increase of Cd accumulation without equilibrium attainment was also found in the euphausiid Meganyctiphanes norvegica by Benayoun et al. (1974). The polychaete $N$. japonica, on the other hand, appears to be a better regulator: $C d$ uptake increased exponentially and almost reached a steady state after 8 days (Ueda and Suzuki, 1976).

The present experiments further indicate that cadmium loads in Ophryotrocha diadema are not transferred to their eggs. Adult $\mathrm{Cd}$ loads correlate non-linearly with exposure-time and experimental concentrations (Fig. 1). Accumulation does not increase within consecutive generations (Fig, 2). Cd contents of the egg masses up to the third generation are very low compared with those of parental individuals and correlate almost linearly with experimental concentrations (Fig. 3). Preliminary investigations on the depuration capacity of adult worms revealed that only about $25 \%$ of the body burden was lost after a depuration period of 56 days following a contamination phase of 95 days during which $\mathrm{Cd}$ accumulation amounted to as much as $2000 \mathrm{ppm}$ (dry weight). No Cd, however,was found in egg masses of the same experimentals after merely 18 days of depuration.

It is assumed, therefore, that the cadmium loads recorded in the egg masses were taken up by sorption of the mucoid encapsulation layer, which is secreted by the parent after deposition of the eggs and fixes them to the substratum. This interpretation is supported by the sorption behaviour of the food particles, which was very similar to that of eggs (Fig. 3).

No definite information on the transfer of heavy metals by marine animals to their eggs has come to my attention. In preliminary experiments with the polychaete Neanthes arenaceodentata, metal loads of 4 consecutive generations exposed to hexavalent chromium seemed to increase successively (Oshida, 1976); however, further experiments could not definitely support these findings (Oshida, 1977). No detectable $\mathrm{Cd}$ loads were found in the offspring of 
long-term contaminated zebrafish Brachydanio rerio by Rehwoldt and Karimian-Teherani (1976).

It is not known how oocytes and eggs evade, regulate or suppress cadmium uptake from contaminated parental tissues and/or from the environment after spawning and before enclosure in their encapsulation layer. No data on the site of deposition of the metal in parental tissues nor in the Cd sorption of single unprotected eggs are available, Recent studies on the $\mathrm{Cd}$ uptake by eggs of different teleost species have shown the metal to be accumulated mainly at the surface of egg capsules, probably forming protein or mucopolysaccharide complexes in the chorion. Despite high metal contents in/on the eggs, newly hatched larvae of Clupea harengus contained only negligible amounts of the toxicant (Rosenthal and Sperling, 1974; von Westernhagen et al.,1974, 1975).

Acknowledgements. I am very indebted to B. Akesson (Göteborg, Sweden) for providing cultures of Ophryotrocha diadema; to O. Kinne for working facilities; to K. R. Sperling for chemical analyses; to H. Rosenthal and H.-P. BuInheim for advice and encouragement; to M. Blake and R. Friedrich for advice regarding the English version of this mamuscript; and to $C$. Schuster for typing. The investigations were financed by a grant of the Deutsche Forschungsgemeinschaft (Kl 367/1-3)

\section{LITERATURE CITED}

Akesson, B. (1970). Ophryotrocha labronica as test animal for the study of marine poliution. Helgolander wiss. Meeresunters., 20, 293-303.

Akesson, B. (1975). Bioassay studies with polychaetes of the genus Ophryotrocha as test animals. In J. H. Koeman and J. J. T. W. A. Strik (Eds), Sublethal Effects of Toxic Chemicals on Aquatic Animals. Proceedings of the SwedishNetherlands Symposium, Wageningen. pp. 121-135.

Ákesson, B. (1976). Morphology and life cycle of Ophryotrocha diadema, a new polychaete species from California. Ophelia, 15, 23-35.

Ayling, G. M. (1974). Uptake of cadmium, zinc, copper, lead and chromium in the Pacific oyster, Crassostrea gigas, grown in the Tamar River, Tasmania. Wat. Res., 8, $729-738$.

Benayoun, G., Fowler, S. W. and Oregioni, B. (1974). Flux of cadmium through euphausiids. Mar. Biol, 27, 205-212.

Boyden, C. R. (1977). Effect of size upon metal content of shellitish. J. max biol. Ass. U. K., 57, 675-714

Bryan, G. W. (1976). Some aspects of heavy metal tolerance in aquatic organisms. In A. P. M. Lockwood (Ed.), Effects of Pollutants on Aquatic Organisms. Cambridge University Press, Cambridge. pp. 7-34.

Bryan, G. W and Hummerstone L. G. (1973). Adaptation of the polychaete Nereis diversicolor to estuarine sediments containing high concentrations of zinc and cadmitim. $J$. mar. biol. Ass. U. K, 53, 839-857.

Dethlefsen, V. (1977). Uptake, retention and loss of cadmium by Crangon crangon. Int. Counc. Explor. Sea Comm. Meet., E: 12, 1-21.

George, S. G. and Coombs, T L. (1977). The effect of chelating agents on the uptake and accumulation of cadmium by Mytilus edulis. Mar. Biol., 39, 261-268.
Gillespie, R., Reisine, T. and Massaro, E. J. (1977). Cadmium uptake by the crayfish, Orconectes propinquus propinquus (Girard). Envir. Res., 13, 364-368.

Jackim, E., Morrison, G. and Steele, R. (1977). Effects of environmental factors on radiocadmium uptake by four species of marine bivalves. Mar. Biol., 40, 303-308.

Kinne, O. (Ed.) (in press). Marine Ecology, Vol. V. Ocean Management, Wiley, Chichester.

Nickless, G., Stenner, R. and Terrille, N. (1972). Distribution of cadmium, lead, and zinc in the Bristol Channel. Mar. Pollut. Bull., 3, 188-190.

Oshida, P. S. (1976). Effects on marine life: effects of chromium on reproduction in polychaetes. Rep. sth. Calif. estl Wat. Res. Proj., 1976, 161-167.

Oshida, P. S. (1977). A safe level of hexavalent chromium for a marine polychaete. Rep. sth. Calif. estl Wat. Res. Proj., 1977, 169-180.

Rehwoldt, R. and Karimian-Teherani, D. (1976). Uptake and effect of cadmium on zebra fish. Bull. envir. Contam. Toxicol., 15, 442-446.

Reish, D. J. and Carr, R. S. (1978). The effect of heavy metals on the survival, reproduction, development, and life cycle for two species of polychaetous annelids. Mar. Poll. Bull., 9. $24-27$.

Rosenthal, H. and Sperling, K. R. (1974). Effects of cadmium on development and survival of herring eggs. In J. H. S. Blaxter (Ed.), The Early Life History of Fish. Springer, Berlin. pp. 383-396.

Schulz-Baldes, M. (1974). Lead uptake from sea water and food, and lead loss in the common mussel Mytilus edulis. Mar. Biol., 25, 177-193.

Sperling, K. R. (1976). Determination of heavy metals in seawater and marine organisms by flameless atomic absorption spectrophotometry. I. Attempts to obtain improved reproducibility by a control of gas movements in the graphite tube atomizer. Atom. Absorp. Newsl., 15, 1-4.

Sperling. K. R. (1977a). Heavy metal determination in seawater and in marine organisms with the aid of flameless AAS. IV Description of a routine method for the determination of cadmium in small samples of biological material. Z. Lebensmittelunters. u. Forsch., 163, 87-91.

Sperling, K.R. (1976b). Determination of heavy metals in seawater and marine organisms by flameless atomic absorption spectrophotometry. VI. Cadmium determination in culture waters from toxicological experiments with marine organisms. Z. analyt. Chem., 287, 23-27.

Sperling, K. R. (1978). Determination of heary metals in seawater and in marine organisms by lameless atomic absorption spectrophotometry. VII. Simple extraction method for determination of extremely low cadmium levels in small seawater samples. 2 . analyt. Chem., 292, 113-119.

Ueda, T R. N. and Suzuki, Y (1976). Comparison of ${ }^{115 m} \mathrm{Cc}$ accumulation from sediments and sea water by polychaete worms. Bull. Jap. Soc. scient. Fish., 42, 299-306.

Westemhagen, $H$. von, Rosenthal, $H$. and Sperling, $K$. R. (1974). Combined effects of cadmium and salinity on development and survival of herring eggs. Helgoländer wiss. Meeresunters., 26, 416-433

Westernhagen, H. von, Dethlefsen, V. and Rosenthal H. (1975). Combined effects of cadmium and salinity on development and survival of garpike eggs. Helgolander wiss. Meeresunters., 27, 268-282.

Zaroogian, G. E. and Cheer, S. (1976). Accumulation of cãdmium by the American oyster Crassostrea virginica. Nature, Lond., 261, 408-410. 